\title{
01 Achieving food security in China Implications of WTO accession
}

\section{Chunlai Chen and Ron Duncan}

The impact of China's entry into the World Trade Organization (WTO) on its agricultural sector has been a major concern of the Chinese government and one of the hottest topics among policymakers and academics inside and outside China. In 1998, the Australian Centre for International Agricultural Research (ACIAR) funded a multi-year research project (ADP/1998/128) to examine the impacts of China's WTO accession on its agricultural sector. The project was a joint undertaking by researchers from Australia and China.

The project began before China's accession to the WTO, but it was anticipated that the accession application would be successful and that it was therefore important to understand fully the impact that the accession commitments could have within China. There was a concern to see that Chinese policymakers appreciated the benefits that would flow from trade liberalisation. At the same time, it was understood that the trade reforms would lead to structural adjustments that would involve the reduction of some activities, with the accompanying loss of employment and asset values. It was believed that it was desirable for policymakers to have an understanding of these consequences, as this would reduce the chances of the adoption of poor policies in response to any perceived or real adverse impacts. Another objective of the project was to analyse various policy options in order to offer input to China's policymaking process. 
China made substantial commitments to freer trade in agriculture in its accession agreement. Underlying these commitments, therefore, is a substantial shift away from its previous basic agricultural policy position, which had an emphasis on food 'self-sufficiency' and restrictions on food imports. As might be expected, there remains strong support for food self-sufficiency policies and agricultural import restrictions, but these policies have very high economic costs for the country because they maintain resources in activities that do not use them efficiently. Therefore, one of the aims of the research project was to demonstrate the high costs of food self-sufficiency policies, in order to reduce the chances of any move back towards such policies.

The research project had a strong general equilibrium focus, which has been followed through the use of global and China-specific computable general equilibrium models and the analysis of the impact of all of China's WTO accession commitments, not only its agricultural commitments. The focus on general equilibrium research has two related justifications. First, when analysing the impacts of agricultural policies, we should look beyond the agricultural sector because agricultural policies will have economy-wide impacts. Analogously, trade policy initiatives in other sectors will have impacts on the agricultural sector. Further, the impact of macroeconomic policies on particular sectors can be as important, if not more important, than sector-specific policies. Second, it is clear from recent experience in developing countries that incomes of rural households are increased more by increases in off-farm income earned by household members than by increases in on-farm income. Therefore, in examining the welfare implications of the trade liberalisation for farm households, it is important to examine all the ways in which farm household incomes could be affected through the structural adjustments to the trade reforms.

This chapter summarises the results of the collaborative research project that has explored various implications of China's accession to the WTO, particularly those relating to agricultural policy and the agricultural sector, and to the issue of food security.

\section{China's agricultural development and policies}

Huang and Rozelle (Chapter 2) review China's agricultural development and its policy regime before and since its accession to the WTO. They 
argue and demonstrate that China's WTO accession commitments are a continuation of policy changes that have been taking place since economic reforms began in 1979. Moreover, they see the accession commitments as verifying a fundamental shift by the government from direct participation in the economy to taking on a more indirect regulatory and fostering role. They see a trend in policies pushing agricultural activities in a direction that is more consistent with the country's resource endowments. The accession agreements will allow more land-intensive products into the domestic market from overseas and stimulate the export of labour-intensive crops.

Huang and Rozelle see the post-WTO accession policy changes taking two basic forms: those changes necessary to honour the obligations of the accession commitments, and those policies necessary to minimise any adverse impacts from the accession commitments. Some of the latter policies include further land reform to allow farm amalgamation, higher productivity and incomes, promotion of farmer organisations, abolition of agricultural taxes and investment in new technology. Overall, Huang and Rozelle see a strong government commitment to modernising the agricultural sector in China.

\section{Food self-sufficiency and food security}

Maintenance of grain self-sufficiency has long been a major plank of China's agricultural policy. As recently as 1996, the Vice-Minister of Agriculture, Wan Baorui (1996), announced that the grain self-sufficiency rate was to be maintained at above 95 per cent. Along with the widening of per capita income disparities between rural and urban areas, the rhetoric of food self-sufficiency is the most prominent weapon of China's protectionists. There has been concern that China will go the way of Japan, Korea and Taiwan and protect its agricultural sector as the sector shrinks in relative importance and national per capita incomes increase. China's accession to the WTO could have come just in time to make this possibility less likely. While WTO accession lessens the risk that the protectionists will succeed, the agriculture ministry has been assigned a prominent role in trade policy formation and negotiation, with the power to press for further agricultural protection on self-sufficiency as well as distributional grounds (Anderson et al. 2002; Tong 2003). 
That there exists genuine concern for food self-sufficiency in China is understandable. Widespread famines have been experienced, although, in hindsight, these have probably been due more to bad policies than to bad weather. Concern about the possibility of food trade embargoes can also be understood-although, again, experience has shown that trade embargoes are difficult to implement (Lu 1997; Yang 2000). The difficulty of financing large volumes of food imports would also have been a legitimate concern in the past; however, this is no longer the case. In 2000, China's total export revenue was about US\$250 billion. The importation of 22 million tonnes of grain (the WTO import quota commitment) would cost US\$3-4 billion-only a small fraction of total export earnings.

Food self-sufficiency is not, however, the same as food security. Food security is a matter of whether households have sufficient income to maintain an adequate diet. The important question with respect to food self-sufficiency for China is the extent to which it is prepared to rely on the international market for the gap between its domestic production and its effective demand. China is such a large country that, inevitably, most of the goods and services consumed have to be produced domestically.

To illustrate the economic costs of adopting policies that aim to maintain grain self-sufficiency near the present level or to increase it, protectionist scenarios were modelled by Duncan et al. (see Chapter 8) using an adaptation of the GTAP model, ${ }^{1}$ a global, multi-region, multiproduct general equilibrium model. Following Yang and Tyers (2000), independent representations of governments' fiscal regimes were added to the standard GTAP base, including direct and indirect taxation, separate assets in each region (currency and bonds) and monetary policies with a range of alternative targets.

In earlier analysis, Yang and Tyers (1989) used a global agricultural sector model to examine the impact of rapid income growth in China on the composition of food consumption and the implications of this for food selfsufficiency. They found that the anticipated redistribution of consumption towards livestock products would raise import demand for feed grains and that this would make the maintenance of self-sufficiency through protection very costly. Because their analysis was restricted to the agricultural sector, however, they could not examine the redistribution and economy-wide 
effects of the protection needed to maintain self-sufficiency. The use of the GTAP model overcomes these limitations.

The modelling first projects the base case to 2010 under conservative output and productivity growth assumptions and then asks two questions. First, if China's present food self-sufficiency rates are to be held constant until 2010, will increases in protection be required? Second, what increases in protection would be required to achieve full food self-sufficiency by 2010 and what would be the economy-wide and distributional effects of this protection? Consistent with Yang and Tyers (1989), the base-case projection to 2010 shows substantial declines in Chinese food self-sufficiency (see Table 1.1), particularly for beverages, livestock products and feed grains (basically as the result of income growth), so that substantial increases in protection are needed to maintain the 2001 levels. To achieve self-sufficiency in all agricultural products by 2010 , considerable further protection would be required. In both cases, this protection would be contractionary and redistributive, and it would retard growth in other sectors. The sensitivity analysis shows that the strength of the results rests quite heavily on some parameters, particularly the income elasticity of demand for livestock products.

The model employs the original GTAP constant difference of elasticities of substitution (CDE) system. Its non-homotheticity is an asset in that it permits a range of income elasticities to exist either side of unity. While this system is more general than the homothetic ones often used in such models, it is still restrictive in the width of the parameter range compared with still more general systems. The CDE system is employed here because of its parametric economy. Because of the restrictiveness of the CDE system, the lower bound for the income elasticity of rice cannot be set below 0.1 , despite evidence suggesting that it is now negative (Ito et al. 1989; Peterson et al. 1991). As a result, the differences between the model's income elasticities of livestock products and processed foods-which are superior goods-and those of grains are likely to be smaller than they really are. One consequence of this is that the results likely underestimate the growth in demand for livestock products and processed foods and hence underestimate the associated derived demand for cereal feeds and other agricultural inputs. This means it is likely that there is a downward bias in the estimates of the cost of achieving and maintaining agricultural self-sufficiency. 
Because the declines in self-sufficiency in the base-case projection to 2010 are significant, the tariffs necessary to retain 2001 self-sufficiency rates are substantial, particularly for the beverages, 'other crops' and livestock product groups (see Table 1.2). These taxes on imports are, effectively, taxes on all China's trade; thus, they also reduce China's exports, causing exporting industries to contract. Overall, the increased protection induces a 1 per cent contraction in gross domestic product (GDP) along with some restructuring across industrial sectors. The more heavily protected agricultural industries are favoured, mostly at the expense of manufacturing, particularly light manufacturing.

The additional tariffs required to achieve full food self-sufficiency by 2010 are very large, particularly on imports in the livestock products, processed food and 'other crops' groups (see Table 1.2). These tariff increases distort incentives in the economy substantially, shifting resources into agriculture and contracting the manufacturing and service sectors. Throughout the economy, this decline in allocative efficiency reduces returns to installed capital and therefore investment. The level of 2010 GDP is reduced by nearly 2 per cent. The tariffs that would achieve agricultural self-sufficiency in 2010 reduce exports from China's growth powerhouse-its light manufacturing industries-by half. Domestic resources are reallocated to the agricultural sector, raising costs in manufacturing and reducing the international competitiveness of China's manufacturing industries. The resulting misallocation of labour is particularly striking. The higher tariffs cause employment in agricultural and food-processing activities to be substantially greater, at the expense primarily of light manufacturing.

Higher agricultural tariffs raise land rents by a considerable margin but reduce real wages and capital returns. Real wages grow less in agriculture and in the modern sector. This is true for production and skilled workers, and it is also true for the owners of physical capital. The capital losses occur because the industries that are hurt by the tariffs are more capital intensive than agriculture. In the end, landholders are the only winners from the tariffs.

We might well ask: what is gained by self-sufficiency? Would food be more readily available in China? No! China's 2010 prices for imported foods would be increased by up to 60 per cent because of the increased tariffs; 
even the prices of home-produced food products would increase by at least 10 per cent. The key consequence of political significance would be a reduction in interdependence with the global economy. This cuts two ways. Reduced reliance on food imports means curtailing the principal source of China's overall economic growth since the 1980s: access to foreign markets for its labour-intensive goods. Curtailed exports reduce its capital returns, thereby cutting incentives for investment and, ultimately, the growth rate of its economy.

Table 1.1 Food self-sufficiency in China, 2001-10 (per cent)

\begin{tabular}{lcc}
\hline & 2001 & 2010 \\
Commodity & 100 & 100 \\
Rice & 99 & 91 \\
Beverages & 94 & 89 \\
Other crops & 99 & 95 \\
Livestock & 88 & 83 \\
Processed food & 99 & 99 \\
Fish & 95 & 94 \\
Minerals & 80 & 80 \\
Energy & & \\
\hline
\end{tabular}

Source: Authors' simulations.

Table 1.2 Changes in tariffs required for food self-sufficiency by 2010 (per cent)

$\begin{array}{lcc}\text { Commodities } & \begin{array}{c}\text { Extra protection to hold self- } \\ \text { sufficiency rates at 2001 levels }\end{array} & \begin{array}{c}\text { Extra protection to achieve } \\ \text { full self-sufficiency }\end{array} \\ \text { Rice } & 0.0 & 0.0 \\ \text { Beverages } & 35.4 & 50.6 \\ \text { Other crops } & 19.2 & 72.7 \\ \text { Livestock } & 39.2 & 78.7 \\ \text { Processed food } & 11.1 & 67.3 \\ \text { Fish } & 16.1 & 31.9\end{array}$

Source: Authors' simulations. The changes in protection are shown as proportional changes to nominal protection coefficients. 


\section{Commodity, regional and household impacts of WTO accession}

The project examined the likely commodity/regional impacts of China's WTO agricultural commitments. This was done through the calculation of 'production concentration indices', which Lu (see Chapter 3) defines as the ratio of the sown area (or output) of the commodity per capita of the agricultural population of a region divided by the same ratio for the country. The interpretation of the index is that a region has a comparative advantage (disadvantage) in the commodity if the production concentration index $(\mathrm{PCl})$ is greater (less) than one (analogous to the use of the export concentration index as a measure of 'revealed' comparative advantage).

The calculations show relatively high $\mathrm{PCls}$ for the labour-intensive commodities (vegetables, fruits, meats and fish products) in the eastern region, relatively low $\mathrm{PCls}$ for these commodities in the western region, and values in between for the central region. On average, the eastern region has comparative advantage in all four labour-intensive commodity groups. The central region has comparative advantage in vegetables and meat products but not in fruits and fish products. The western region does not have comparative advantage in any of the four labour-intensive product groups.

PCls for the land-intensive products (grains, oil seeds, cotton and sugar) are relatively high for the western region, relatively low for the eastern region and in between for the central region. The western region has comparative advantage in all four land-intensive commodity groups, while the central region has comparative advantage in grains, oil seeds and sugar. In the eastern region, only sugar has comparative advantage.

In assessing the adjustment impacts of the reduction in protection for agricultural commodities, Lu argues that, in line with China's perceived comparative advantage, liberalisation will strengthen the tendency for imports of land-intensive commodities and encourage exports of labourintensive commodities. It is expected that the export promotion effect will follow closely the regional distribution of comparative advantage of labour-intensive commodities. With regard to the negative importsubstitution effect, the study postulates two possibilities: one is that imports of land-intensive products will substitute largely for domestic production in the regions with relatively high domestic production costs 
for these commodities. The second is that imports will substitute for domestic production in proportion to the existing regional concentration of the commodities.

The two possibilities will have different implications for regional adjustment costs. The first is to be preferred, as it allows the principle of comparative advantage to play a larger role in resource allocation. The second, less desirable, possibility is in line with the policy stance that has emphasised provincial grain self-sufficiency. Under the first scenario, those provinces with comparative advantage in labour and land-intensive commodities will have relatively small adjustment costs. Those provinces without comparative advantage in labour-intensive or land-intensive commodities are likely to be worst off as they will benefit least from export expansion and have to bear the largest adjustment costs. The eastern region is seen as likely to be the major beneficiary from export expansion of labour-intensive products, while the inland regions are expected to receive much smaller benefits. On the other hand, the coastal regions could experience a larger share of the adjustment costs from the import growth while inland provinces could have less adjustment.

Under the second scenario, the regional distribution of the importsubstitution effects changes considerably. The central and western regions could incur a large share of the adjustment costs-that is, they are likely to have a combination of small export-promoting effects and large adjustment costs. This could result in an increase in the income gap between the coastal and inland regions.

To maximise the likelihood for scenario one to materialise, agricultural policies should be changed in a more market-oriented manner. There should be a move away from the emphasis on regional self-sufficiency. As well, the state monopolies in domestic marketing and distribution of bulk agricultural commodities as well as in transport should be removed to allow goods to flow more freely across provincial borders.

In another of the project studies, Jiang (2002) examined the growing income gap between the coastal and inland regions for the period 19782000. This study found that the gap was unchanged or had even declined from 1978 to 1990-the period in which China undertook major agricultural reforms and experienced high growth in the agricultural sector. This development favoured the poorer regions that had higher agricultural 
shares in total output. In the period 1991-2000, however, which followed the major industrial reforms, the eastern region benefited most from growth of foreign investment and development of the private sector. During this time, the regional income gap between the coastal and inland regions widened considerably. Income disparity within the regions, however, declined.

The increasing gaps between rural and urban incomes and between incomes in coastal and inland regions are of considerable concern in China. The likelihood of WTO accession increasing these disparities was a major factor behind resistance to accession. Jiang (see Chapter 6) modelled how WTO accession was likely to affect these income disparities using the CERD model developed under this project (Chen and Duncan 2008).

In simulations of the WTO accession commitments, crops, food processing, motor vehicles and parts, and machinery sectors are affected adversely by the accession, particularly the motor vehicles and parts sector. Other sectors benefit, particularly the light manufacturing sector. Agricultural production declines most in the eastern region and least in the central region. The study results show the usefulness of general equilibrium analysis, which has taken account of there being a higher return to labour-intensive activities outside of agriculture in the eastern region. The eastern region does by far the best overall because it realises most of the gains in allocative efficiency. Hence, there is an increase in regional income disparity. Rural household incomes increase most in the eastern region because they have the best opportunities for earning off-farm income. Across the regions, however, rural household incomes increase less than urban household incomes.

In the project, Jiang (see Chapter 7) also undertook some simulations to examine the impacts of policies that could be adopted to mitigate these adverse effects on farm incomes. One policy option tested was the use of a production subsidy. It was found that if agriculture were to be subsidised to maintain the pre-accession grain self-sufficiency rate, the subsidy would be 7.2 billion yuan. If the target were to maintain the food self-sufficiency rate, the subsidy would be 180 billion yuan. Another policy option tested was an increase in agricultural research and development to improve agricultural productivity. It was estimated that China would have to almost double the level of agricultural research and development in order to maintain the food self-sufficiency rate. 


\section{Surplus agricultural labour}

Another of the project studies (Wang, Chapter 5, and Wang 2002) argued that a major reason for the widening rural-urban income gap since 1991 was the excess supply of labour in agriculture. This excess supply results in low labour productivity-much lower than in the industrial and tertiary sectors-and slower growth in incomes. As a result of the slower productivity growth and the excess of labour in agriculture, the agricultural share of GDP fell from 51 per cent in 1952 to only 14 per cent by 2002, while the share of agricultural workers in the total work-force declined only from 84 per cent in 1952 to 50 per cent in 2002. The share of the rural population in the national total declined even more slowly-from 85 per cent in 1953 to 61 per cent in 2002. The excess supply of labour in agriculture has been attributed in large part to the restrictions on the movement of people from rural areas to cities, accompanied by discrimination in the form of denial of access to housing, education, job training and health facilities.

Because of the development of rural industries, the sources of rural household income have changed remarkably. In 1990, the agricultural share of rural household incomes was 74 per cent. By 2002, this share had fallen to 47 per cent. The development of the rural industrial sector-particularly the township and village enterprise (TVE) sector-was very important in providing opportunities for diversification of rural household incomes. Employment in the TVE sector increased from 28 million to 135 million in the period 1978-96, accounting for more than one-quarter of the rural labour force (Wang and Duncan, Chapter 4, and Wang and Duncan 2003). Despite this, the number of farmers has increased and there appears to be more surplus agricultural labour than ever. The diversification of rural household incomes varies greatly between the major geographical regions, with the share of off-farm income in rural households in the coastal region about 75 per cent but about only 25 per cent in the western region. Moreover, the rural-urban income disparity has widened most in the western region: between 1980 and 2000, the rural/urban income ratio fell from 54.4 per cent to 43.2 per cent in the eastern region, from 49.5 per cent to 40.1 per cent in the central region, and from 44.9 per cent to 30.4 per cent in the western region. 
Development of rural industries slowed in the late 1990s, due mainly to greater market competition, the unfavourable location of rural enterprises, difficulties in accessing external finance and lack of infrastructure, technical inputs and human resources. Meanwhile, urbanisation accelerated and larger numbers of rural labourers moved to urban areas in search of jobs. In 2001, the urbanisation rate (the ratio of urban to total population) in China reached 38 per cent, compared with 26 per cent in 1990 and 19 per cent in 1980.

\section{Restrictions on migration}

In spite of the acceleration of urban development, the urbanisation rate in China is, on average, 10-20 percentage points lower than in other countries at a similar income level-even allowing for the so-called 'floating population' (Wang and Xia 1999). In particular, there are relatively few medium and large cities. In 2001, 121 million people-only 9.6 per cent of the population-lived in cities of more than 500,000 people. In the less-developed western region, only 5.6 per cent of the population lived in cities of that size. If China had an urbanisation rate similar to that of other countries of a similar income level, an additional 120-240 million people would be living in urban areas. This number can be thought of as the excess number of people in the rural economy (see Wang and Duncan, Chapter 4).

Wang and Duncan (Chapter 4 ) note that there are positive correlations between rural industrialisation (measured as the share of TVE employment in rural labour) and rural incomes and between the urbanisation rate and rural incomes. They therefore undertook a causality test of the relationship between urbanisation and regional economic growth. Because urbanisation and rural incomes could be a function of economic growth, the causality test was carried out within an endogenous growth model. The results from the modelling indicate that each percentage point increase in the urbanisation rate increases provincial economic growth by 0.37 percentage points above the already high 7-10 per cent growth rate-that is, urbanisation has a longrun impact on economic growth. When regional dummies are introduced, there are seen to be significant impacts from urbanisation on economic growth in the eastern and central regions, but the impact is insignificant in the western region. There could be two reasons for this last result: the rate 
of urbanisation in the western region has been low and the urban economy in the western provinces has not experienced much restructuring, and is therefore less market-oriented and less efficient.

\section{Macroeconomic implications of WTO accession}

Most other studies of China's WTO accession have focused on the medium and long-run impacts of accession. There are, however, important shortrun issues, in particular those relating to the macroeconomic policy environment in which the reforms take place. The study by Tyers and Rees (see Chapter 9 and 2002) therefore examined the short-run impacts of the reforms under scenarios of capital controls, fixed and floating exchange rate regimes and alternative fiscal policies.

An adaptation of the GTAP model similar to that used in Duncan et al. (see Chapter 8) was used for the analysis. Because of the inclusion of independent representation of governments' fiscal regimes (with inclusion of direct and indirect taxation) and monetary policies with a range of targets, it is possible to study a range of policy regimes. To be representative of short-run conditions, the model also allows for labour market rigidity and departures from full employment.

In order to undertake the short-run analysis, a simulation of the longrun effects of the accession commitments was first carried out. The results allowed for a derivation of investors' expectations on the assumption that they took changes in long-run returns on installed capital into account in determining short-run changes in their investment behaviour. The results from the long-run simulation show the expected allocative efficiency gains from the trade reform, which are reflected in increased GDP and increased returns on installed physical capital, which induce greater investment and larger net inflows on the capital account. The increased average long-run return on installed capital is therefore part of investors' expectations in the short run and so tends to increase the level of investment in the short run-even if capital controls are maintained. The trade reforms also cause consumption to switch away from home-produced goods and the relative prices of such goods to fall, and hence there is a real depreciation. There is also an increase in export competitiveness, and exports expand. 
Manufacturing, particularly light manufacturing, is the main beneficiary of the trade liberalisation, together with the transport sector. This resultwhich is contrary to intuition from the Heckscher-Ohlin-Samuelson (HOS) trade model-derives from the model's departure from the HOS model in two ways: first, there is extensive use of intermediate inputs from the same sector (intra-industry trade); and second, competing imports are differentiated from home products. Under these assumptions, the tariff reductions on imported intermediate inputs have a direct effect on the home industry's total cost. The indirect effect of the reductions in tariffs on competing but differentiated products depends on the elasticity of substitution between imports and home-produced goods. For manufacturing, the input-cost effect of tariff reductions is considerably greater than the impact from the loss of protection against competing imports. Cost reductions of similar origin are the reason for the gains accruing to the domestic transport sector.

As the reforms cause the most substantial reductions in protection in China's food-processing sector and therefore lead to long-run contractions in rice and 'other crops', there is substantial relocation of employment from agriculture to the manufacturing, energy and transport and other services sectors.

\section{Simulations of short-run effects}

For the short-run base-case simulation, China is assumed to maintain a fixed exchange rate against the US dollar and rigid capital controls, while nominal wages are 'sticky'. The other regions specified in the model have inflation and CPI targeting, no capital controls, full short-run nominal wage rigidity in the industrial countries and fully flexible nominal wages elsewhere. Government spending in all regions is assumed to absorb a fixed proportion of GDP and the rates of direct and indirect taxes are constant, so that government deficits vary in response to shocks.

Five different macroeconomic regimes were simulated to study the impact of the trade reforms.

1. Rigid capital controls and fixed tax rates; monetary policy targets the $\mathrm{CPI}$, and the exchange rate floats. 
2. Fixed exchange rate and fixed tax rates; there are no capital controls.

3. Fixed tax rates, monetary policy targets the CPI, the exchange rate floats and capital controls are removed.

4. Rigid capital controls and a fixed exchange rate; the direct tax rate adjusts to maintain the government deficit as a fixed proportion of GDP.

5. The closure is the same as number four, however, capital controls are removed.

The short-run effects of the trade reform vary considerably under the different macroeconomic regimes. When capital controls are in place and the exchange rate is fixed, the allocative gains from the tariff reductions are insufficient to offset the contractionary effects of the deflation that is due to the rise in the relative prices of foreign goods. When capital controls are weak, the trade liberalisation attracts increased inflows on the capital account and mitigates the real depreciation and associated domestic price deflation. The real volume of investment rises irrespective of the target of monetary policy, as does the level of GDP. The choice of monetary policy still matters, however, with CPI targeting leading to a smaller GDP price deflation, more modest gains in the real production wage and better short-run GDP gains.

As with monetary policy, the impact of the different fiscal policies depends on the strength of capital controls. Given tight capital controls, if tax rates are held constant and the fiscal deficit expands, domestic interest rates rise and private investment is crowded out. Where income tax increases to compensate for the tariff cut, there is less pressure on the domestic capital market and the interest rate increase is less, as is the fall in investment. In the absence of effective capital controls, the case of no increase in the tax rates performs better than the alternative policy. The increased government borrowing draws in international savings at international interest rates and does not crowd out private investment. Both fiscal policies, however, give superior results in the absence of capital controls. 
The key determinant of the short-run structural adjustment resulting from the trade liberalisation is the size of the real depreciation; the real depreciation is larger when capital controls are in place. Traded-goods sectors, such as light manufacturing, are advantaged while non-traded sectors are not. When there are no capital controls, the manufacturing gains are smaller and the non-traded services sectors also benefit. Across the board, however, for the same reasons as in the long-run simulation, agriculture and food processing are disadvantaged by the reforms. It is important to note that some relaxation of the monetary policy regime can reduce the adverse effects on the agricultural sector from the trade reform. When capital controls are in place and the exchange rate is fixed, almost the entire agricultural sector is hurt. Where capital controls are in place but the exchange rate is floated, the 'other crops', livestock and fisheries sectors expand.

Employment in food processing falls regardless of the macroeconomic policy regime. Significant structural change is required in the short run with the movement of employment from agriculture to manufacturing; however, in the long run, the size of the employment shift is smaller. Under either fiscal regime, the greatest contraction in employment in food processing occurs when capital controls are tight and monetary policy targets the nominal exchange rate. Unlike in the long run, employment in the other agricultural sectors is not necessarily contractionary-the outcome is dependent on the macroeconomic policy regime.

In summary, if capital controls are too tight and the fixed nominal exchange rate is retained, the reforms are deflationary. If the labour market is slow to adjust, employment growth will slow and the reform package will be contractionary. To obviate this, the government has to allow sufficient net inflow on the capital account to at least maintain the level of domestic investment. If it does not do this, a small nominal depreciation would achieve the same result. The fiscal policy response to the loss of import revenue has comparatively little influence on China's economic performance in the short run. Regardless of whether government spending or the government deficit is held constant, the optimal macropolicy environment is a floating exchange rate with no capital controls. 


\section{Macroeconomic impacts on migration}

In a follow-up study to Tyers and Rees (see Chapter 9 and 2002), Chang and Tyers (see Chapter 10 and 2003) analyse the slow-down in China's income growth since the East Asian financial crisis. In particular, they examine the slow-down in rural income growth and the widening rural-urban income gap and ask to what extent this is due to: 1) the remaining obstacles to rural-urban migration (as suggested by lanchovichina and Martin 2002); 2) the WTO trade reforms (as suggested by Anderson et al. 2002); or 3) restrictive macroeconomic policies. Using the GTAP model adaptation of Tyers and Rees (see Chapter 9), ${ }^{2}$ the researchers test the extent to which China's fixed exchange rate and capital controls-and its WTO accession commitments-have contributed to the relatively poor performance of the rural sector. The East Asian financial crisis was seen as leading to a large (largely illegal) outflow of capital. This capital flight and the trade reforms are hypothesised to have led to a real exchange rate depreciation. The pegging of the yuan to the US dollar has therefore necessitated a deflation. If wages are 'sticky' and fall more slowly than prices, employment declines. It is hypothesised that the resulting real wage increase in the modern sectors has reduced labour demand and hence 'bottled up' workers in the rural sector and reduced rural per capita incomes.

Analysis of the data shows that while restraints on rural-urban migration have been relaxed to some extent, the migration flow has decreased rather than increased. The simulation results support the hypothesis that the fixed exchange rate and the capital controls have restricted the flow of workers from the rural sector. The model shows the rate of migration into the manufacturing sector falling by at least one percentage point a year and into the services sector by at least two percentage points a year. In all sectors there is a stark contrast between employment growth under tight capital controls and a fixed exchange rate regime on the one hand and an open capital account and floating currency regime on the other. Indeed, with an expansionary macroeconomic policy and optimistic assumptions about the productivity effects associated with the WTO accession reforms, simulated worker relocation demands from the reforms exceed the average 
of China's recent rural-urban performance. This suggests that there is ample scope for a more rapid rate of migration of labour out of the rural sector, which would help reduce the rural-urban income gap.

\section{China's agricultural trade after WTO accession}

Chen (see Chapter 11) examines how the pattern of China's agricultural trade has changed since the country's accession to the WTO. In that time, the economy has grown very rapidly. The average annual growth rate of China's real GDP was more than 9.8 per cent during 2002-05. China's foreign trade has been expanding even more rapidly-at an annual growth rate of 28.6 per cent, compared with 9.4 per cent during the 1990s. Undoubtedly, China's economy has benefited from its more open international trade regime.

In real terms, China's agricultural exports and imports hardly changed in the period 1992-2001; but since then both have increased rapidly, although imports have grown much more rapidly than exports-so much so that in 2004 and 2005 China experienced its first agricultural trade deficits since at least the early 1990s. Chen shows that the changes in China's trade since 2001 have been strongly consistent with the country's comparative advantage, which is in labour-intensive activities. While increasing very rapidly, agricultural exports have, however, become a considerably smaller share of total trade. Moreover, within agricultural trade, processed agricultural products are dominating exports and imports are being dominated increasingly by cereals, vegetable oils and oil seeds, and raw materials for textiles. Processed agricultural products are labourintensive activities, while cereals, vegetable oils and oil seeds, and raw materials for use in textiles are land-intensive activities.

\section{Implications of the ASEAN-China Free Trade Agreement}

In parallel with WTO accession, China has also engaged actively in regional and bilateral free trade agreements (FTAs). At present, China has bilateral FTAs with Pakistan, Chile, Jordan, Thailand, the Association of South-East Asian Nations (ASEAN) (currently the Early Harvest Program, EHP, is in operation but the full FTA is not expected until 2010), Hong Kong and Macau (as a Closer Economic Partnership Arrangement, CEPA). China is currently 
negotiating free trade agreements with Australia and New Zealand, and has proposed to negotiate FTAs with South Korea and India. ${ }^{3}$ Among these bilateral FTAs, the ASEAN-China Free Trade Agreement (ACFTA) could have the largest impact on the economies of China and ASEAN.

Agricultural trade between China and ASEAN: complementary or competitive?

Yang and Chen (see Chapter 12) show that bilateral agricultural trade between China and ASEAN has increased rapidly in recent years, especially since the negotiation and implementation of the ACFTA and the launch of the EHP. ASEAN's agricultural exports to China have increased rapidly, reaching US\$5 billion in 2005. China's agricultural exports to ASEAN have also increased but at a slower pace, reaching US\$2.2 billion in 2005. ASEAN has been enjoying an increasing surplus with China in agricultural trade.

The share of exports to China in ASEAN's total agricultural exports has increased rapidly from 4.8 per cent in 1999 to 10.2 per cent in 2005. China became the third largest export market for ASEAN's agricultural products in 2005. With the full implementation of the ACFTA, the share is expected to rise further. A similar trend has not, however, been witnessed with respect to China's exports to ASEAN.

Yang and Chen find that agricultural trade between China and ASEAN is more complementary than competitive. China can be expected to export more labour-intensive agricultural products to ASEAN and import more land-intensive agricultural products from ASEAN. As China's revealed comparative advantage (RCA) in labour-intensive agricultural products is higher than that of ASEAN, it should be possible for China to increase its exports to ASEAN in these kinds of agricultural products (that is, fruits and vegetables, processed products, animal products and fish). Compared with China, ASEAN has an overwhelming comparative advantage in certain landintensive agricultural products (such as rubber and palm oil). Therefore, both sides will be better off if they exploit their comparative advantage in agricultural sectors by deeper integration of their economies.

The agricultural production structure in ASEAN has experienced some adjustments to match Chinese market demand. The trade complementary index (TCl) for ASEAN's exports and China's imports in food and living 
animals (SITC0) rose from 1.0 in 1998 to 1.23 in 2005. The TCI for ASEAN's exports and China's imports of all agricultural products also increased quickly, from 1.07 in 2001 to 1.48 in 2005. These trends demonstrate that the complementarity of ASEAN's exports and China's imports has been increasing in recent years. This implies that ASEAN might have undergone a structural adjustment in its agricultural sectors in response to China's rising status as an export destination for its agricultural products. Such an adjustment has not, however, been witnessed in China-at least, not one as significant as in ASEAN.

It should be relatively easy for ASEAN to gain access to the Chinese market during the integration between the two economies. The high and increasing value of the TCI for ASEAN's exports and China's imports reveals the strong market match between ASEAN and China: ASEAN is selling what China wants to buy. Therefore, the structural adjustment in agricultural production in ASEAN (shown by the rising TCl) should improve ASEAN's capacities to grasp the opportunities provided by China's huge market.

There is, however, also competition in some agricultural products and certain structural adjustments are inevitable. For example, as China's imports from ASEAN in tropical fruits increased quickly in recent years, many Chinese farmers producing tropical fruits in coastal areas found that they were losing profits and domestic market shares (Newspaper of Southern Agriculture 2006). As a result, many fruit trees have been destroyed. Therefore, certain policies should be taken to assist the transition to different farming activities or to help farmers move to non-agricultural sectors.

\section{Economic effects of the ASEAN-China Free Trade Agreement}

Yang and Chen (see Chapter 13) assessed the economic effects of the ACFTA in its two stages up to 2010. The analysis is based on an improved recursive GTAP model. The data are based on Version 6.0 of the GTAP database for 2001, together with data derived from other sources. There are two distinguishing characteristics of this study. The first is that, in addition to the commitments in the ACFTA, it incorporates trade liberalisation in China (China's WTO commitments) and trade liberalisation in ASEAN (ASEAN free trade commitments). The second is that it has separated and explored the different effects of the two-stage implementation of the ACFTA. 
Yang and Chen find that all member countries will gain from the ACFTA: it will increase social welfare and promote real GDP growth in the EHP phase of 2004-06 and in the full implementation during 2006-10. As the EHP includes only a small package of agricultural commodities, the gains in the second stage of the full implementation of the ACFTA will be much larger in all member countries.

There is a large trade creation effect among ACFTA members; total exports of ACFTA members will increase. A trade diversion effect is, however, also apparent. Trade between ACFTA members and other regions can be expected to decline due to the creation of the ACFTA. Because the trade creation effect is much larger than the trade diversion effect, global trade will be increased by the ACFTA, especially in the second stage of its full implementation.

The ACFTA will bring about substantial structural changes in China and in ASEAN countries. Trade liberalisation will improve the exploitation of comparative advantages in ACFTA member states. The structural changes will take place in agricultural and industrial sectors. The results also show that the different policy arrangements stemming from the two-stage trade liberalisation will have different impacts on the shifts in economic structure during the process of implementation.

The rest of the world will have to face the challenges brought about by the creation of the ACFTA. Because the ACFTA will enhance the competitiveness of China and ASEAN in each other's markets, exports of non-member countries will be substituted. Social welfare and real GDP will decline in the nonmember countries as a result of the creation of the ACFTA.

\section{Summary and discussion}

Across the wide range of analysis carried out in this project, it is shown consistently that the trade reforms China adopted in order to accede to the WTO will mean substantial structural changes within the agricultural sector. Looked at from a partial equilibrium agricultural perspective, the reforms can be seen to result in substantial negative impacts across the sector and a worsening of food security in the sense of reduced access to income. It cannot be stated too strongly, however, that the outcomes of the reform have to be analysed from an economy-wide perspective. In China, as 
in other rural-based countries, the main factors behind reductions in rural poverty will be the scope for rural households to earn off-farm income and for people to move from rural areas into industrial and services activities in urban centres. Therefore, to a very large extent, the success of the trade reforms will depend on policies beyond agriculture.

There was considerable internal resistance to China joining the WTO, with concern about food security (more commonly seen in China as food self-sufficiency) and the perceived adverse impacts on the agricultural sector. The analysis carried out in this project has confirmed that structural change driven by productivity growth-which the trade reforms will promote-will lead to agriculture becoming a smaller and smaller part of the economy. As incomes increase, consumption patterns change and the share of agriculture shrinks, China will become less self-sufficient in many commodities. Because it has such a large population, however, China will always have to produce most of the food that it consumes. As the modelling has shown, trying to hold this development at bay or reverse it would have exorbitant costs. No doubt, however, there will continue to be resistance to the reforms in agriculture. The large proportion of the population that is still supported by agriculture can be a significant political weapon. Unfortunately, resistance to reforms can prevent exploitation of the potential for their incomes to increase, thus providing further ammunition for arguments to provide government support for the sector. It is important, therefore, that the economic arguments against 'food self-sufficiency' be made over and over.

The gap between urban and rural incomes has widened in the past decade or so. Partly, this is an outcome of the very rapid growth of the urbanised industrial and services sectors, but it is also the result of a slowing of the growth of rural incomes. This is partly the result of the slow-down in the growth of the TVE sector and the lessened opportunities for rural households to earn off-farm incomes. Incomes in the agricultural sector have not grown as rapidly as they could because of poor agricultural policies, such as ineffective and costly price support policies, regional self-sufficiency policies and monopolistic marketing and distribution of bulk commodities, fertilisers and seeds. China's accession to the WTO should help to maintain pressure to bring about reforms in these areas. 
The current government grain reserve system is inefficient in many respects and very costly. It is run by different government agencies at the central, provincial and municipal levels, each with different interests and not very clearly defined roles. These arrangements give rise to conflicting interests in operations dealing with market instability and cannot serve the goal of food security well. A smaller, well-managed grain reserve system with a clear, single objective would better serve this goal. It should be understood, however, that grain markets will never operate efficiently while there is a government-run storage system, as it will crowd out efficient private storage.

The restrictions on rural-urban migration and constraints on the development of urban centres have also restricted opportunities for the rural-urban income gap to be reduced. The research shows that urbanisation has significant positive impacts on rural incomes and regional economic growth. The development of urban centres, particularly in inland regions, appears to be a matter of high priority. The 'keep them down on the farm' policy of China (and many other developing countries) seems to be due partly to a concern about problems associated with urban development, such as congestion and pollution. Urban centres should, however, be seen in a positive light. They exist because they provide efficiencies of scale and scope. Problems associated with cities derive largely from the lack of good planning of infrastructure, inappropriate property rights to land and inappropriate taxes and subsidies. China should therefore persist with infrastructure development to promote inland cities as an offset to the geographical disadvantages of the inland regions. Otherwise, it will face continued pressures for migration to the coastal cities. Removal of the remaining restrictions on rural-urban migration and discrimination against rural migrants should accompany the promotion of the development of urban centres.

It is shown that rural households in the coastal region will do best from the trade reforms as they have the most opportunity for earning income in off-farm employment. These opportunities arise because the nonagricultural industries in the eastern region benefit most from the trade reforms. This is partly the result of the bulk of private-sector development having taken place in this region. The government should reduce its support 
of state-owned enterprises (SOEs) in the inland regions, which crowd out private enterprises. The private sector, however, also needs the government to provide infrastructure to overcome the geographical disadvantages of the inland regions.

The modelling has also shown that China's monetary policy regime of the fixed yuan and capital controls has increased the rural-urban income gap by raising real wages and reducing employment growth in the nonagricultural sectors. The results show that moving away from this monetary policy regime could lead to a much more rapid relocation of labour out of agriculture and thereby promote a reduction in the rural-urban income gap.

A monetary policy regime change could also reduce the adverse impacts of the WTO trade reforms on the agricultural sector. Modelling with capital controls in place and the fixed exchange rate results in almost the entire agricultural sector being adversely affected by the tariff reductions. Even partial relaxation of the monetary policy regime could reduce this adverse impact. For example, when capital controls are in place but the exchange rate is floated, the 'other crops', livestock and fisheries sectors expand.

The government is, however, right to undertake any change in its monetary policy regime gradually and cautiously, as shown by the East Asian financial crisis. Adoption of a floating exchange rate would be premature, considering the underdeveloped state of China's financial sector, its only partially reformed banking sector and its still-vulnerable SOEs. The priority at this stage should be to accelerate the reforms in each of these areas.

\section{Notes}

1 A detailed description of the original model is provided by Hertel (1997).

2 The key difference between the long-run analysis in this paper (Chapter 10) and that in Tyers and Rees (Chapter 9) is that in the model used for the simulations reported in this paper (Chapter 10) there is an assumed positive relationship between the trade reforms and productivity growth.

3 See http://en.wikipedia.org/wiki/List_of_free_trade_agreements 


\section{References}

Anderson, K., Jikun, H. and lanchovichina, E., 2002. 'Impact of China's WTO accession on rural-urban income inequality', presented at the Australian Agricultural and Resource Economics Society Pre-Conference Workshop on WTO: Issues for Developing Countries, Canberra, 12 February.

Chang, J. and Tyers, R., 2003. Trade reform, macroeconomic policy and sectoral labour movement in China, Working Papers in Economics and Econometrics, No.429, Faculty of Economics and Commerce, The Australian National University, Canberra.

Chen, C. and Duncan, R., 2008. Achieving Food Security in China: implications of WTO accession, ACIAR Technical Reports No.69, Australian Centre for International Agricultural Research, Canberra.

Hertel, T. (ed.), 1997. Global Trade Analysis Using the GTAP Model, Cambridge University Press, New York.

lanchovichina, E. and Martin, W., 2002. Economic impacts of China's accession to the WTO, World Bank Policy Research Working Paper 3053, The World Bank, Washington, DC.

Ito, S., Peterson, E. and Grant, W., 1989. 'Rice in Asia: is it becoming an inferior good?', American Journal of Agricultural Economics.

Jiang, T., 2002. 'WTO Accession and Regional Incomes', in R. Garnaut and L. Song (eds), China 2002: WTO entry and world recession, Asia Pacific Press, Canberra:45-62.

Lu, F., 1997. Food trade policy adjustment in China and an evaluation of the risk of a food embargo, Working Paper C1997007, China Centre for Economic Research, Peking University, Beijing.

Newspaper of Southern Agriculture, 2006. 'Pressures by ASEAN fruit import', 18 April.

Peterson, E., Jin, L. and Ito, S., 1991. 'An econometric analysis of rice consumption in the People's Republic of China', Agricultural Economics, 6(1):67-78.

Tong, J., 2003. 'WTO commitment: further marketisation and trade liberalisation', in R. Garnaut and L. Song (eds), China 2003: new engine of world growth, Asia Pacific Press, Canberra:141-51.

Tyers, R. and Rees, L., 2002. Trade reform in the short run: China's WTO accession, Paper presented to ACIAR Project 98/128 Workshop at 
the China Centre for Economic Research, Peking University, Beijing, September.

Wan, B., 1996. Prospect and policy of China's agricultural development, Keynote speech by the Agricultural Vice-Minister, Wan Baorui, to the international symposium on China's Grain and Agriculture: Prospect and Policy, 7 October, Beijing.

Wang, X., 2002. 'The WTO challenge to agriculture', in R. Garnaut and L. Song (eds), China 2002: WTO entry and world recession, Asia Pacific Press, Canberra:81-95.

Wang, X. and Duncan, R., 2003. 'The impact of urbanisation on economic growth', in R. Garnaut and L. Song (eds), China 2003: new engine of world growth, Asia Pacific Press, Canberra:217-30.

Wang, X., and Xia, X., 1999. 'Optimum city size and economic growth', Economic Research, (9), Beijing.

Yang, Y., 2000. Are food embargoes a real threat to China?, Mimeo., National Centre for Development Studies, The Australian National University, Canberra.

Yang, Y. and Tyers, R., 1989. 'The economic cost of food self-sufficiency in China', World Development, 17(2):237-53.

--, 2000. China's post-crisis policy dilemma: multi-sectoral comparative static macroeconomics, Working Papers in Economics and Econometrics, No.384, Faculty of Economics and Commerce, The Australian National University, Canberra. 